DOE Final Report

October 9, 2002

*To be cntcred into DOE's electronic database directly http://www.sc.doe.gov/rims/scripts/rims.exe Password: 695046, User ID: ANDREWS

\title{
Summary of findings:
}

Our project analyzed the challenges raiscd by complex genetic disordcrs in genetic counseling, for clinical practice, for public hcalth, for quality assurance and for protection against discrimination. Our research found that, in some settings, solutions created in the context of single gene disorders are more difficult to apply to complex disorders. In other settings, the single gene solutions actually backfired and created additional problems when applied to complex genetic disorders. We also evaluated indepth the literature of five common, complex genctic disorders: Alzheimer's, asthma, coronary heart disease, diabetes and psychiatric illnesses.

\section{Methodology:}

We started our project by collecting medical, legal, epidcmiological, psychological, and ethical articles dealing with complex genetic disorders. A second stage of the project focused on the extent to which the medical, legal, ethical, and psychological articles acknowledged the range of ethical issues raised by complex genctic disorders and the aspects of those issues that are unique. In that analysis, we collected all articles related to genetic testing for five complex genetic disorders (Alzheimer's, asthma, coronary hear diseasc, diabetes and psychiatric illnesses) and analyzed the extent to which the articlcs acknowledged, compared, or analyzed the existence of ethical, legal, or social challenges present when testing for complex genelic disorders.

We then analyzed the way in which courts in cases involving negligence law and discrimination law have addressed genetic testing and genctic disease. This aspect of the study attempted to predicl whether complex genetic diseascs would be handled differently than single gene disorders.

Findings:

Background Concerns with Complex Disorders

Obtaining informed consent in the realm of complex genetic diseases is complicated by the potential for multiple diagnoses. Paticnts seeking testing for one specific complex disease may find in the process that they are at increased risk for another complex disease for which they were not inquiring. The presence of a variant of the apolipoprotein E (ApoE) allclc, for example, is a marker for coronary heart diseasc but the ApoE-4 variant is also a marker for Alzhcimer's disease. Is the clinician ethically obliged to inform the patient of the presence of the predisposing gene for Alzheimer's disease when the patient did not consent to the test or knowledge of the in formation? This is a concem bccause the patient did not provide informed consent to tcst for several genes. 


\section{DISCLAIMER}

This report was prepared as an account of work sponsored by an agency of the United States Government. Neither the United States Government nor any agency thereof, nor any of their employees, makes any warranty, express or implied, or assumes any legal liability or responsibility for the accuracy, completeness, or usefulness of any information, apparatus, product, or process disclosed, or represents that its use would not infringe privately owned rights. Reference herein to any specific commercial product, process, or service by trade name, trademark, manufacturer, or otherwise does not necessarily constitute or imply its endorsement, recommendation, or favoring by the United States Government or any agency thereof. The views and opinions of authors expressed herein do not necessarily state or refleet those of the United States Government or any agency thereof. 


\section{DISCLAIMER}

Portions of this document may be illegible in electronic image products. Images are produced from the best available original document. 
The discovery of one's yenotype through genetic testing has profound implications for individual self-esteem and self-perception. Much research has been conducted within the single gene diseascs assessing the individual's psychosocial risks based on the results of genetic tcsts. These risks are simply magnified in the arena of multifactorial disease. Knowing the presence of onc "defective" gene can lead a pcrson into severe depression, but the knowledge of scveral "defective" genes without a clear sense of their meaning and implication for future disease has the potcntial for devastating results. Genetic knowledge, despite its nuances and inaccuracies, can alter people's ideas of self-efficacy, estccm, personal locus of control and even risk-taking behaviors. But information about complex genetic disorders may have a lesser impact on individuals because the predictive value of a test is so much lower than the predictive value of the test for a single genc disorder.

Information about complex genctic disorders may have little impact on aclual decisions. For example, despite the hypothesis that smokers who knew they had a higher risk for cancer based on genetic test results would be more inclined to quite smoking, the early data from smoking research shows no greater likelihood among smokers who were informed of their genctic cancer risk to quit smoking. Research revcals that the genetic information provides no grcat motivation, but also does not undermine a person's desire to quit. Given the interplay between genetic factors, cnvironmental influences and risktaking behaviors in the development of complex discase, the belief among many public health experts that the knowledge of one's genetic information will lead to a more informed lifestyle and will be an important catalyst for preventive mcdicine may be unrealistic.

In analyzing the writings on complex, genetic disorders we found that none addressed the full range of potential ethical issues involved and only a few pointed out the unique issues that genetic complexity raiscd.

\section{Legal Ramifications}

In our lcgal analysis, we found that under the Amcrican with Disabilities Act (ADA), people who have a record of, are regarded as having, or do have a disability are protecled from discrimination in employment and in the provision of health care services. More controversial are conditions that might make the person less likely to want to reproduce, bringing that person within the protection of the ADA since reproduction has been interpreted by courts to be a major life function. AlDS is such a condition, but so, too, might be some untreatable dominant single gene disorders, such as Huntington's disease. Courts' focus in interpreting the ADA has been on the severity of the disorder. Thus the ADA has application for complcx multifactorial diseascs where the manifestation is severe, such as coronary artery disease.

As people begin to undergo genetic testing for complex, common disorders, however, questions have been raised as to just what constitutes a disability under the ADA. For example, whether an alleged genetic predisposition to develop carpal tunnel syndrome should be considered a disability under the ADA is an issue currently being litigated.

In the context of negligence, when people seek genetic testing, genetic counseling or other genetic information, health care providers have an obligation to provide it in a high quality way. Whien patients might benelit from genetic services, physicians have a legal obligation to offer them. Medical malpractice cases have held hcalth care providers liable 
for not informing patients they were in a high-risk group with respect to certain genetic risks and for not performing genetic tests accurately. In the negligence context, some courts have only allowed recovery if the disorder at issue was severc, but they have sel a different standard for severity than in the ADA context.

The rationale for finding physicians liable for negligence is that such liability deters low quality genetic services. However, the vast majorily of these cases deal with single gene disorders such as Tay-Sachs disease or chromosomal abnormalities such as Down syndrome. The courts in the cases involving malpractice liability in the genetic testing arena have assumed that the test not offered or undertaken incorrcctly was highly predictive. The harm in the casc was in not providing the patient with highly predictive genetic information. How then will low quality genetic services be deterred in the arena of complex, common disorders if such precedents are followed and courts refuse to find liability for failure lo offer a test or failure to pcrform it correctly?

We found that, at the federal level, the Equal Employment Opportunities Commission has interpreted the Americans with Disabilities Act to cover individuals with genetic predispositions to later develop particular diseases. The focus is on the phenotype, and whether it constitutes a disability. A disability is a condition that interferes with a major life function, such as blindness, paralysis, or coronary artery disease. In contrast, negligence law uses a differenl standard for disability. For cxample, one court has suggested that blindness would not be a sufliciently severe disability for parents to recover damages if the obstetrician failed to advise them of a genetic test to predict blindness or a laboratory failed to undertake the test accurately.

Courts have primarily dealt with single gene disorders and chromosomal abnormalities in instances where the probability of a disorder manifested is highly predictive. One court indicated that negligence would not be found if a physician fails to offer a test that would only have predicted $20 \%$ of the instances of the disorder. Yet, when dealing with complex, common disorders, a particular genetic lest may not predict more than $20 \%$ of the cases.

This led us to consider whethar a new policy might need to be inslituted in the negligence area that is closer to the ADA approach that focuses on the nature of the . disorder rather than the nature of the genetic test for the disorder.

We also found that there were particular difficulties in the intellectual properly arena in applying the rationales from the single gene context to the complex genetic disease context. This led to publication of an article and a further grant submission.

Describe papers and other products delivered: "The Gene Patent Dilemma: Balancing Commercial Incentives With Health Needs," Houston Journal of Health Law $\&$ Policy (Forthcoming 2002). This project led to the subnission of a larger proposal which was funded: "Complex Genetic Disorders and Intellectual Property Rights," Office of Science (BER), U.S. Department of Energy, Grant No. DE-FG02-02ER63460.

Any new notes concerning the project: ( 5,000 characters or less) 